\title{
Reaction Rate Constants of Urea in Sandy Clay Loam Soils
}

\author{
S. Hemalatha* \\ Kumaraguru Institute of Agriculture, Sakthinagar - 638315, Erode District, India \\ *Corresponding author
}

\begin{tabular}{|c|c|}
\hline & A B S T R A C T \\
\hline Keywords & \multirow{4}{*}{$\begin{array}{l}\text { An incubation experiment was conducted at Water Technology Centre, Tamil Nadu } \\
\text { Agricultural University, Coimbatore during } 2011 \text {, to study the reaction rate constants of } \\
\text { urea under sub-tropical conditions. The different concentration of urea was used with } \\
\text { constant moisture and temperature. The values for } \mathrm{K}_{\mathrm{HU}} \text {, (hydrolysis rate constant) observed } \\
\text { were } 0.014,0.0134,0.0139 \text {, and } 0.0140 \mathrm{~h}^{-1} \text { for } 1.582,3.71,37.04 \text {, and } 55.55\left(\mathrm{mg} \mathrm{N} / \mathrm{cm}^{3}\right) \text {, } \\
\text { respectively. The } \mathrm{K}_{\mathrm{D}} \text {, (distribution rate coefficient) values observed were } 0.0138,0.03465 \text {, } \\
0.03386 \text {, and } 0.0139 \mathrm{~h}^{-1} \text { for } 1.582,3.71,37.04 \text {, and } 55.55\left(\mathrm{mg} \mathrm{N} / \mathrm{cm}^{3}\right) \text {, respectively. } \mathrm{K}_{\mathrm{V}} \text {, } \\
\text { volatilization coefficient values observed were } 0.0070,0.0078,, 0.0083 \text { and } 0.0071 \mathrm{hr}^{-1} \text { for } \\
\text { the urea } \mathrm{N} \text { concentrations of } 1.582,3.71,37.04 \text {, and } 55.55\left(\mathrm{mg} \mathrm{N} / \mathrm{cm}^{3}\right) \text {, respectively. And } \\
\text { the } \mathrm{K}_{\mathrm{N}}, \text { nitrification rate constant values were } 0.0076,0.0074,0.0074 \text { and } 0.0077 \mathrm{~h}^{-1} \text { for } \\
1.582,3.71,37.04 \text {, and } 55.55\left(\mathrm{mg} \mathrm{N} / \mathrm{cm}^{3}\right) \text {, of urea doses respectively. }\end{array}$} \\
\hline $\begin{array}{l}\text { Urea, Reaction rate } \\
\text { constant, Moisture, } \\
\text { Temperature }\end{array}$ & \\
\hline Article Info & \\
\hline $\begin{array}{l}\text { Accepted: } \\
\text { 10 February } 2019 \\
\text { Available Online: } \\
10 \text { March } 2019\end{array}$ & \\
\hline
\end{tabular}

\section{Introduction}

The dynamics of nitrogen in soil- water atmosphere system is of considerable interest in many agricultural applications, including the development of cost effective and environmentally sound nutrient management practices. Urea is the widely used nitrogenous fertilizer. Indian fertilizer industry is urea based and may remain as the main source of $\mathrm{N}$ for many years to come. In soil, the applied urea is hydrolyzed by the enzyme urease of rhizosphere microorganisms to ammonium and nitrate which are prone to losses through volatilization, denitrification and leaching. Hydrolysis of urea followed the first order kinetics in different soils. The rate of urea hydrolysis varied markedly with the soil type and was positively and significantly correlated with organic carbon and clay contents of soils. Hongprayoon et al., (1991) reported that urea hydrolysis rates were variable and increased with incubation time and followed the first order reaction kinetics. And also the rate of disappearance of urea followed first -order kinetics and the rate constants $\left(\mathrm{K}_{\text {rea }}\right)$ were variable and increased with incubation time (Bouldin et al., 1991).

Urea hydrolysis required a parameter accounting for an activation time, which was found to be greater at relatively higher urea concentrations and at lower experimental temperatures (Bolado et al., 2005) 
The effectiveness of nutrient supply control in increasing nutrient use efficiency and reducing environmental problems depends on two factors viz., matching nutrient supply with crop demand and maintaining nutrient availability (Avishaviv, 2000).

Most of the nutrient transformations in soil are concentration dependent. This implies that supply of any nutrient exceeding the plant's uptake ability is likely to provoke processes that will decrease its concentration in the soil. Such process includes transformations induced by microbes (nitrification, denitrification and immobilization), chemical reactions (exchange, fixation, precipitation and hydrolysis) and physical processes viz., leaching, run off, and volatilization. Hence, the present study was undertaken to find out the reaction rate constants of urea to use the data in the modeling studies, in turn for the fertigation schedule for the crops based on the crop needs.

\section{Materials and Methods}

A laboratory study was conducted in a sandy clay loam soil to investigate the reaction rate constants of urea at different concentrations at Water Technology Centre, Tamil Nadu Agricultural University, Coimbatore.

Soil was collected from the irrigation cafeteria of Eastern Block, Tamil Nadu Agricultural University farm. The texture of the soil was found to be Sandy Clay loam (scl). Soil samples were shade dried and sieved through $2 \mathrm{~mm}$. Experiments were carried out in $500 \mathrm{~mL}$ conical flasks containing $400 \mathrm{~g}$ of dry soil treated with commercial urea at different concentrations. In order to study the effect of urea concentration on ammonia volatilization the soils were treated with known concentration of urea ranging from lower to higher concentrations. To maintain the uniform soil moisture level initially the soils were homogenized with known volumes of distilled water. Subsequently the field capacity was maintained based on the moisture content of the sample. Then, the containers were sealed using septa with input - output gas connections and incubated for 11 days. The temperature during the incubation period was maintained at $25-28{ }^{\circ} \mathrm{C}$. The experimental system was designed to obtain a constant air flow rate of approximately $5 \mathrm{~L} / \mathrm{min}$ over the urea fertilized soils. Air was introduced to the flasks using a diaphragm pump which forced air to first pass through a safety trap to prevent any flux of liquid in case of system failure. The safety trap was followed by a system for humidification of the air, calibrated to maintain a stable level of humidity in the samples during the experiment, and a trap containing boric acid in order to prevent the entry of ammonium. The air exiting from the soil containing test flasks was passed through $200 \mathrm{~mL}$ of an aqueous 2 per cent boric acid solution in order to collect the volatilized ammonium. In order to increase the amount of volatilized ammonium available for detection, group of flasks were arranged in parallel under identical working conditions. Periodic tests showed no air losses from the containers and connections in the experimental array. Emission of volatilized ammonia was determined by periodic titration of the boric acid solution against $0.02 \mathrm{~N} \mathrm{H}_{2} \mathrm{SO}_{4}$. At the end of the experiments, final concentrations of nitrate and ammonia were determined in the soils.

\section{Analysis of experimental results}

The results obtained from the experiment was analyzed using excel package, by downloading Risk Solver platform trial version. The data were analyzed using standard LSRG non linear engine with multi start option. 


\section{Finding the reaction rate constant}

First order equation for Urea Hydrolysis and the equation obtained after integration

$$
\begin{aligned}
& \frac{\partial \theta U}{\partial t}=-K_{H U} \theta U \\
& \frac{\partial \theta U}{(\theta U)}=-K_{H U} \partial t \\
& {[\ln \theta U]_{\theta_{0} U_{0}}^{\theta_{t} U_{t}}=-K_{H U}[t]_{0}^{t}} \\
& \ln \theta_{t} U_{t}-\ln \theta_{0} U_{0}=-K_{H U} t \\
& K_{H U}=\left(-\ln \theta_{t} U_{t}+\ln \theta_{0} U_{0}\right) / t \\
& \ln \left(\frac{\theta_{t} U_{t}}{\theta_{0} U_{0}}\right)=-K_{H U} t \\
& e^{-K_{H U} t}=\frac{\theta_{t} U_{t}}{\theta_{0} U_{0}} \\
& U t_{t}=\left(\frac{\theta_{0} U_{0}}{\theta_{t}}\right) e^{-K_{H U} t}
\end{aligned}
$$

Where $\mathrm{U}_{\mathrm{t}}$ and $\mathrm{U}_{0}$ is urea concentration at time ' $\mathrm{t}$ ' and at time zero, $\theta_{\mathrm{t}}$ and $\theta_{0}$ are moisture contents at time $\mathrm{t}$ and at time zero and $\mathrm{K}_{\mathrm{HU}}$ is reaction rate constant for urea hydrolysis.

This equation can be used for estimating the concentration of urea at any time $t$ if the moisture contents at the start $\theta_{0}$, the urea applied at the start $\mathrm{U}_{0}$ and the reaction rate constants are known.

If soil moisture is maintained at approximately a constant level,

$$
(\theta \mathrm{U})_{\mathrm{t}}=(\theta \mathrm{U})_{0} \mathrm{e}^{-\mathrm{K}}{ }_{\mathrm{HU}} \mathrm{t}
$$

\section{Urea ammonium Equation}

$\frac{\partial(\theta C)}{\partial t}+\rho \frac{\partial S}{\partial t}=-k_{v} \theta C-k_{N} \theta C+K_{H U} \theta U$

$S=K_{D} C$

Where $\mathrm{C}=$ concentration of $\mathrm{N}-\mathrm{NH}_{4}{ }^{+}$in the soil solution

$\mathrm{S}=$ concentration of $\mathrm{N}-\mathrm{NH}_{4}{ }^{+}$adsorbed to the solid phase

$\mathrm{P}=$ soil bulk density

$\mathrm{K}_{\mathrm{v}}=$ volatilization rate constant

$\mathrm{K}_{\mathrm{N}}=$ nitrification rate constant

$\frac{(\theta C)_{t+\Delta t}-(\theta C)_{t}}{\Delta t}\left(1+\frac{\rho K_{D}}{\theta}\right)=\left(K_{v}+K_{N}\right)(\theta C)_{t}+K_{H U} \theta U_{t}$

$(\theta C)_{t+\Delta t}-(\theta C)_{t}=\left\{\frac{\Delta t}{\mid 1+\frac{\rho K_{D}}{\theta}} \mid\left[-\left(k_{v}+k_{N}\right)(\theta C)_{t}+K_{H U} \theta U_{t}\right]\right.$

$(\theta C)_{t+\Delta t}=(\theta C)_{t}+\left(\frac{\Delta t}{1+\frac{\rho K_{D}}{\theta}}\right) \mid\left[-\left(k_{v}+k_{N}\right)(\theta C)_{t}+K_{H U} \theta U_{0} e^{-k}\right.$

The volatilized ammonia till any time ' $t$ ' from the start can be found out by the following equation.

$$
\begin{aligned}
& A V_{t}=\int_{0}^{t} K_{v}(\theta C)_{t} d t \\
& A V_{t}=\sum_{0}^{t} K_{v}(\theta C)_{t} \Delta t
\end{aligned}
$$

\section{Initial experimental conditions employed} (Table 1)

Table 1 summarizes the initial experimental conditions employed for finding out the reaction rate constant for urea. The 
experiment was carried out during the month of June 2011. The temperature during the study period was collected from the nearby meteorological observatory and the average temperature prevailed during the study period was $27^{\circ} \mathrm{C}$. Four different doses of urea were used and moisture $\left(0.33 \mathrm{~cm}^{3} / \mathrm{cm}^{3}\right)$ level was maintained.

\section{Results and Discussion}

\section{Urea hydrolysis and reaction rate}

Historically, the main problem with the use of urea as $\mathrm{N}$ source has been the control of ammonia losses by preventing urea hydrolysis as these two processes are strongly coupled in soils. An extensive list of models exists for studying the use of $\mathrm{N}$ in agriculture and minimizing $\mathrm{N}$ losses to the environment. These models differ from each other in terms of their representation of the processes involved, the invoked numerical algorithms, and applicable working scales. Initially, most of the models had a fixed objective, and focused on specific processes such as volatilization of ammonia (Parton et al., 1981), or lixiviation of nitrates (Addiscott, 1981). With greater sophistication of a model, the more likely that the model will be able to accurately represent the actual $\mathrm{N}$ transformation process within a given application. Unfortunately the number of required parameters also increases with increased complexity of the model. Parameter uncertainty can also lead to inaccurate applications. Thus, the main limitations in the use of $\mathrm{N}$ fate and transport models are inadequate representation of the coupled processes involved (Diekkruger et al., 1988) and the difficulty of obtaining input parameters for the models (De Willigen, 1991; Schmied et al., 2000). The parameters may be obtained independently from correlations or laboratory assays, or by means of field experiments and parameter optimization using inverse simulation techniques. When the objective of a study involves the application of a predictive model at a field scale, the use of inverse simulation techniques in conjunction with the field data is probably the more efficient alternative (Ritter, 2002).

The objective of the present study was to generate and analyze the data for $\mathrm{N}$ transformations in soils fertilized with urea. This requires the characterization of the main $\mathrm{N}$ transformation processes (i.e. urea hydrolysis, ammonia adsorption, volatilization and nitrification) and analyzing the effect of initial concentration of urea on the transformations.

The first order volatilization coefficient obtained in the present study was 0.0052 to $0.0083 \mathrm{~h}^{-1}$. Bolado et al., (2005) obtained first - order coefficients for volatilization of $0.0023 \mathrm{~h}^{-1}$. Differences may be due to the better control of evaporation of water in the present investigation. Moreover, Bolado et al., (2005) conducted experiment in the laboratory condition, but in the present case, it was carried out in the field condition where the bottles with soil were placed in the soil. The temperature of the soils was maintained at $28{ }^{\circ} \mathrm{C}$ throughout the experiment.

In the present investigation, the distribution coefficient $\mathrm{K}_{D}$ obtained was $0.034 \mathrm{~h}^{-1}$ for sandy clay loam soil and this finding was in agreement with Hongprayoon et al., (1991), whom recorded the $\mathrm{K}_{D}$ of $0.03 \mathrm{~h}^{-1}$ for medium textured soil.

With regard to urea hydrolysis constant $\mathrm{K}_{H U}$ recorded $0.0134 \quad \mathrm{~h}^{-1} \quad$ whereas, Bolado et al., (2005) observed that the urea hydrolysis constant $\mathrm{K}_{H U}$ of $0.05 \mathrm{~h}^{-1}$ which were following the first order kinetics (Table 2 and 3 ). 
Table.1 Initial Experimental conditions employed for finding out the reaction rate constant for urea

\begin{tabular}{|c|c|c|c|c|}
\hline $\begin{array}{c}\mathrm{U}_{0}(\mathbf{m g} \mathbf{N} / \\
\left.\mathbf{c m}^{3}\right)\end{array}$ & Soil & $\begin{array}{c}\theta \\
\left(\mathrm{cm}^{3} / \mathrm{cm}^{3}\right)\end{array}$ & $\begin{array}{l}\text { Final concentration of } \\
\mathrm{NH}_{4} \text { - Nin soil }\left(\mathrm{mg} \mathrm{cm}^{3}\right)\end{array}$ & $\begin{array}{l}\text { Final concentration of } \\
\mathrm{NO}_{3} \mathrm{~N} \text { in soil }\left(\mathrm{mg} \mathrm{cm}^{3}\right)\end{array}$ \\
\hline 1.852 & SCL & 0.33 & 0.328 & 0.592 \\
\hline 3.71 & SCL & 0.33 & 0.540 & 0.750 \\
\hline 37.04 & SCL & 0.33 & 1.52 & 6.500 \\
\hline 55.55 & SCL & 0.33 & 2.02 & 10.750 \\
\hline
\end{tabular}

$\theta$, soil volumetric water content, $\mathrm{U}_{0}$ initial concentration of urea-N in solution

Table.2 Quantity of ammonia volatilized over the period of time

\begin{tabular}{|c|c|c|c|c|}
\hline \multirow{2}{*}{$\begin{array}{c}\text { Time in } \\
\text { hours }\end{array}$} & \multicolumn{4}{|c|}{ Ammonia volatilized $\left(\mathbf{m g ~ \mathbf { ~ m } ^ { \mathbf { 3 } } )}\right.$} \\
\cline { 2 - 5 } $\mathbf{0}$ & $\mathbf{U}_{\mathbf{0}}=\mathbf{1 . 8 5 2}$ & $\mathbf{U}_{\mathbf{0}}=\mathbf{3 . 7 1}$ & $\mathbf{U}_{\mathbf{0}}=\mathbf{3 7 . 0 4}$ & $\mathbf{U}_{\mathbf{0}}=\mathbf{5 5 . 5 5}$ \\
\hline $\mathbf{1}$ & 0 & 0 & 0 & 0 \\
\hline $\mathbf{2}$ & 0.001 & 0.001 & 0.004 & 0.005 \\
\hline $\mathbf{4}$ & 0.002 & 0.002 & 0.005 & 0.006 \\
\hline $\mathbf{2 4}$ & 0.004 & 0.002 & 0.015 & 0.02 \\
\hline $\mathbf{4 2}$ & 0.009 & 0.002 & 0.084 & 0.092 \\
\hline $\mathbf{6 5}$ & 0.010 & 0.049 & 0.09 & 0.095 \\
\hline $\mathbf{8 9}$ & 0.03 & 0.073 & 1.05 & 1.35 \\
\hline $\mathbf{1 1 3}$ & 0.043 & 0.086 & 1.08 & 1.54 \\
\hline $\mathbf{1 4 0}$ & 0.047 & 0.095 & 1.12 & 1.84 \\
\hline $\mathbf{1 6 4}$ & 0.056 & 0.113 & 1.15 & 1.48 \\
\hline $\mathbf{1 9 2}$ & 0.046 & 0.092 & 0.98 & 1.05 \\
\hline $\mathbf{2 1 6}$ & 0.021 & 0.043 & 0.24 & 0.54 \\
\hline $\mathbf{2 4 0}$ & 0.007 & 0.015 & 0.22 & 0.22 \\
\hline $\mathbf{2 6 4}$ & 0.006 & 0.012 & 0.008 & 0.008 \\
\hline Total & 0.001 & 0.003 & 0.004 & 0.004 \\
\hline
\end{tabular}

Table.3 Values of the optimized model parameters

\begin{tabular}{|c|c|c|c|c|}
\hline $\mathbf{U}_{\mathbf{0}}\left(\mathbf{m g ~ N} / \mathbf{c m}^{\mathbf{3}}\right)$ & $\begin{array}{c}\mathbf{K}_{\mathbf{H U}} \\
\left.\mathbf{( h}^{-\mathbf{1}}\right)\end{array}$ & $\begin{array}{c}\mathbf{K}_{\mathbf{D}} \\
\left.\mathbf{( h}^{-\mathbf{1}}\right)\end{array}$ & $\begin{array}{c}\mathbf{K}_{\mathbf{v}} \\
\left(\mathbf{h}^{-\mathbf{1}}\right)\end{array}$ & $\begin{array}{c}\mathbf{K}_{\mathbf{N}} \\
\left(\mathbf{h}^{-\mathbf{1}}\right)\end{array}$ \\
\hline $\mathbf{1 . 8 5 2}$ & 0.014 & 0.01387 & 0.0070 & 0.0076 \\
\hline $\mathbf{3 . 7 1}$ & 0.0134 & 0.03465 & 0.0078 & 0.0074 \\
\hline $\mathbf{3 7 . 0 4}$ & 0.0139 & 0.03386 & 0.0083 & 0.0074 \\
\hline $\mathbf{5 5 . 5 5}$ & 0.0140 & 0.0139 & 0.0071 & 0.0077 \\
\hline
\end{tabular}

$\mathrm{U}_{0}$, initial concentration of urea-N in solution; $\mathrm{K}_{\mathrm{HU}}$, hydrolysis rate constant; $\mathrm{K}_{\mathrm{D}}$, distribution rate coefficient; $\mathrm{K}_{\mathrm{v}}$, volatilization coefficient; $\mathrm{K}_{\mathrm{N}}$, nitrification rate constant

The first- order nitrification coefficient for the soil were obtained in the range of 0.0074 to
$0.0077 \mathrm{~h}^{-1}$ for different concentrations of urea. Wagenet et al., (1977) and Bolado et al., (2005) 
reported the nitrification coefficient value of $0.002 \mathrm{~h}^{-1}$. There was no marked difference in the value with the increase in the urea concentration. A possible explanation for this is that the temperature and moisture controls the reaction rate which was maintained constant for all the urea doses applied.

In conclusion, the results showed that the amount of volatilized ammonia is higher when the urea concentration is higher. The hydrolysis rate constant of urea increased with the increased urea concentrations. The observed volatilization rate constant increased with increasing urea concentration. The distribution coefficient tends to decrease with the increased urea concentration. The nitrification rate constant found to increase with the increased urea concentration. The reaction rate constants were worked out from the incubation experiment on which there is less work carried out in India. These results can be used for predicting model related with urea as $\mathrm{N}$ source.

\section{References}

Addiscott, T.M.1981. Leaching of nitrate in structure soils.p.245-253.InFrissels, M.J and Van Veen, J.A.(ed). Simulation of nitrogen behavior of soil- plant systems. PUDOC, Wageningen, the Netherlands.

Avishaviv, A. 2000.Advances in controlled release fertilizers. In: Adv. Agron. Vol. 71 (Ed.) Donald, L. Academic press, New York. pp. 1-49.

Bolado, R., G. Alonso and Alvarez,B. 2005. Characterization of nitrogen transformations, sorption and volatilization process in urea fertilized soils. Vadose Zone J., 4: 329-336.

Bouldin, D.R., C. Hongprayoon, C.W.Lindau, and Patrick, Jr. 1991.Urea transformations in flooded soil columns. II. Derivation of model parameters and implications to ammonia volatilization. Soil Sci. Soc. Am. J., 55: 1135- 1142.

De Willigen,P. 1991. Nitrogen turnover in the soil-crop system: Comparison of fourteen simulation models. Fert. Res., 27:141-149.

Diekkruger, R.B.,D.E.Kissel, J.K. Koelliker, and Basel,W.1988. Ammonia volatilization from surface-applied urea: Effect of hydrogen ion buffering capacity. Soil Sci. Soc. Am. J. 48:578582.

Hongprayoon, C., C. N. Lindau, W.H. Patrick, D.R. Bouldin and Reddy, K.R. 1991. Urea transformation in flooded soil columns: International experimental results. Soil Sci. Soc. Am. J., 55: 11301134.

Parton, W.J., W.D. Gould, F.J. Adamson, S. Torbit, and Woodmanse, R.G.1 981. $\mathrm{NH}_{3}$ volatilization model. p. 233-244. In M.J. Frissel and J.A. van Veen (ed.) Simulation of nitrogen behavior of soil plant systems. PUDOC, Wagenigen, the Netherlands.

Ritter, A. 2002.Optimizacion de la simulaciondeltransporte de aguay solutes en suelosporagroquimicos. Ph.D thesis. Univ. de Cordoba, Spain.

Schmied, B., K. Abbaspour, and Schulin,R. 2000. Inverse estimation of parameters in a nitrogen model using field data.Soil Sci. Soc. Am. J., 64: 533-542

Wagenet, R.J., J.W. Biggar, and Nielsen, D.R. 1977. Tracing the transformations of urea fertilizers during leaching. Soil Sci. Soc. Am. Proc., 41: 896-902.

\section{How to cite this article:}

Hemalatha, S. 2019. Reaction Rate Constants of Urea in Sandy Clay Loam Soils. Int.J.Curr.Microbiol.App.Sci. 8(03): 877-882. doi: https://doi.org/10.20546/ijcmas.2019.803.105 